\title{
Use of Bacteriocin Producing
} Lactococcus lactis subsp. lactis LABW4 to Prevent Listeria monocytogenes Induced Spoilage of Meat

\author{
Soma Barman, Ranjan Ghosh, Narayan C. Mandal* \\ Mycology and Plant Pathology Laboratory, Department of Botany, Visva-Bharati, Santiniketan, India \\ Email: mandalnc@rediffmail.com
}

Received 25 September 2014; revised 20 October 2014; accepted 15 November 2014

Copyright (C) 2014 by authors and Scientific Research Publishing Inc.

This work is licensed under the Creative Commons Attribution International License (CC BY). http://creativecommons.org/licenses/by/4.0/

\section{(c) (7) Open Access}

\begin{abstract}
A bacteriocin producing strain of Lactococcus lactis subsp. lactis LABW4 was isolated from naturally fermented milk product which exhibited strong antibacterial activity against Listeria monocytogenes MTCC657, a food spoilage psychrophilic organism. Both cell free and heat killed supernatants of LABW4 were effective to produce zones of inhibition against $L$. monocytogenes in vitro. The antibacterial metabolite(s) of LABW4 showed strong cidal effect on the growth of $L$. monocytogenes. Meat samples, mixed with heat killed supernatant of LABW4 when inoculated with Listeria, remain fresh up to 25 days in refrigerated condition whereas spoilage started immediately after 24 hours of inoculation for control sets. Enhancement of Lactate dehydrogenase of L. monocytogenes upon treatment with LABW4 cell free supernatant suggested its lytic mode of action. Cell lysis or degradations were also supported by scanning electron micrograph of treated cells.
\end{abstract}

\section{Keywords}

Lactic Acid Bacteria, Bacteriocin, Spoilage of Meat, Listeria monocytogenes, Lactate dehydrogenase

\section{Introduction}

Lactic acid bacteria are Gram positive, usually non motile, non spore forming rods and cocci. The cellular energy of lactic acid bacteria is derived from the fermentation of carbohydrates to produce principally lactic acid. Along with their common fermentation properties these group of bacteria are the good source of different kinds

"Corresponding author.

How to cite this paper: Barman, S., Ghosh, R. and Mandal, N.C. (2014) Use of Bacteriocin Producing Lactococcus lactis subsp. lactis LABW4 to Prevent Listeria monocytogenes Induced Spoilage of Meat. Food and Nutrition Sciences, 5, $2115-$ 2123. http://dx.doi.org/10.4236/fns.2014.522224 
of antimicrobial compounds like organic acids, diacetyl, hydrogen peroxide and proteinaceous bacteriocins [1]. From the very early periods till now lactic acid bacteria are used as biopreservatives because most of the bacteria in this group are reported as generally recognised as safe (GRAS). So now a day's lactic acid bacteria are used to prevent food spoilage replacing the commonly used chemical preservatives.

Bacteriocins produced by lactic acid bacteria are small, ribosomally synthesized, antimicrobial peptides or proteins. A large number of bacteriocin produced by different lactic acid bacteria have been characterized. Several studies have suggested that LAB starter cultures or co-cultures are able to produce their bacteriocins in food matrices, and consequently display inhibitory activity towards sensitive food spoilage or pathogenic bacteria [2].

The Gram positive bacteria Listeria monocytogenes is a common food borne pathogen and is responsible for several outbreak of food borne diseases. The organism occurs widely in different food products, with the highest incidences being found in poultry, meat, and seafood products [3]. Because of its widespread occurrence in nature and its ability to tolerate environmental stresses such as low $\mathrm{pH}$, low temperature and salt concentration up to $10 \%$, the potential for post processing contamination of foods with L. monocytogenes is high [4] [5].

Control of Listeria monocytogens using bacteriocin producing lactic acid bacterial strains has been reported by several workers. One such organism, Pediococcus acidilactici, produces a bacteriocin which was effective to inhibit L. monocytogenes in some dairy products [6]. Buyong et al. [7] studies on use of a genetically engineered Lactococcus lactis subsp. lactis MM217 to control Listeria monocytogenes in cheddar cheese.

In the present work we have tried to study the anti-listerial activity of a lactic acid bacterium LABW4 isolated from good quality fermented milk product. In addition to check the anti-listerial activity of LABW4 in vivo, we have also tried to control the spoilage of meat caused by Listeria monocytogenes by challenge study.

\section{Materials and Methods}

\subsection{Isolation of Lactic acid Bacteria}

Lactic acid bacterial strains were isolated from good quality fermented milk product on de Man Rogosa and Sharpe (MRS) [8] agar plates and their bacteriocin producing ability was initially screened using sensitive organism Enterococcus faecalis MB1(LAB8) by dual culture overlay method [9]. After the appearance of white colonies on MRS agar plates, the plates were overlaid with sensitive strain. The bacterial strains which can produce the inhibition zones against the sensitive organism were picked up and purified by streaking on MRS agar plates and the strain LABW4 was taken as potent one for further studies. Identification of the strain LABW4 was done based on morphological, biochemical and 16S rRNA gene sequence homology studies.

\subsection{Antimicrobial Activity of LABW4 against Listeria monocytogenes}

Antibacterial activity of LABW4 against Listeria monocytogenes MTCC657 was checked by agar well diffusion method [10] as well as by counting the colony forming units (CFUs). LABW4 was grown in MRS broth at $28^{\circ} \mathrm{C}$ and the cell free supernatant was taken after centrifugation at 10,000 rpm for 10 minutes and pH was adjusted to 7. Cell free supernatant as well as heat killed cell free supernatants $50 \mu \mathrm{l}$ each were added to the wells of nutrient agar plates containing L. monocytogenes. Uninoculated MRS broth (pH 7) was used as control. All the plates were incubated at $28^{\circ} \mathrm{C}$ for 24 hours. Next day, the zones of inhibition were observed and diameters were measured. Antibacterial activity of the cell free supernatant of LABW4 was also checked after treatment with proteinase K (200 AU/ml).

The antilisterial activity of LABW4 was also checked by counting the colony forming units in the presence and absence of cell free supernatant ( $\mathrm{pH} 7$ ) of LABW4. L. monocytogenes was inoculated (1\%) to $10 \mathrm{ml}$ nutrient broth and treated with cell free supernatant of LABW4 (1\% to 10\%). In control set unionculated MRS broth was used in place of cell free supernatant. The tubes were incubated at $28^{\circ} \mathrm{C}$ for 24 hours. Next day $100 \mu l$ of Listeria culture was spread on nutrient agar (NA) plates after proper dilution and the plates were incubated at $28^{\circ} \mathrm{C}$ for 24 hours. The numbers of colony forming units were counted and compared.

\subsection{Study of Mode of Action}

To check the mode of action of bacteriocin produced by LABW4 on L. monocytogenes, growth pattern of the pathogen in the presence and absence of cell free supernatant of LABW4 were studied. $1 \%$ of L. monocytogenes culture was added in to two different sets of sterilised $10 \mathrm{ml}$ nutrient broth and incubated at $28^{\circ} \mathrm{C}$. At the mid log phase of the growth (10.5 hours) cell free supernatant (10\%) of LABW4 was added to one set and considered as 
treated set [11]. The other set was considered as control where only uninoculated MRS broth was added and was incubated. Then the tubes were again incubated. Colony forming units were counted from the initial phase at every 1.5 hours intervals by spreading $100 \mu \mathrm{l}$ of culture from both the sets after proper dilution. The growth pattern of L. monocytogenes in the presence of cell free supernatant was compared with the control set.

\subsection{Control of Spoilage of Meat Caused by Listeria monocytogenes Using LABW4}

Meat samples were cut into small pieces and were divided into four sets in petriplates in equal amounts (10 gm in each set). The petriplates with meat samples were wrapped with aluminium foil and autoclaved for proper sterilization. After sterilization the first and second sets were treated with $10 \mathrm{ml}$ of $L$. monocytogenes $\left(10^{6}\right.$ $\mathrm{CFU} / \mathrm{ml}$ ) suspended in $50 \mathrm{mM}$ phosphate buffer. The second and third sets of meat samples were treated with cell free supernatant of LABW4 and the fourth set was considered as untreated one. So the second sets were treated with both $L$. monocytogenes as well as cell free supernatant of LABW4. All of the plates were incubated at $4^{\circ} \mathrm{C}$ upto 25 days. The colony forming units of L. monocytogenes were counted for each set at five days of intervals. 1gm of meat sample was taken from each set, homogenized with sterilized tissue homogenizer and suspended in $10 \mathrm{ml}$ of sterilized distilled water. $100 \mu \mathrm{l}$ of suspension was taken and sprayed on nutrient agar plates after proper dilution to count the colony forming units.

\subsection{Lactate dehydrogenase (LDH) Assay}

The activity of the cytoplasmic enzyme Lactate dehydrogenase (LDH) from L. monocytogenes was measured following the method of Stockland and San Clemente [12] with little modification. The enzyme was prepared from overnight culture of L. monocytogenes resuspended in $50 \mathrm{mM}$ Tris-chloride buffer (pH 7.5) (OD 2.0 at 620 $\mathrm{nm}$ ). In one part, $1 \mathrm{ml}$ of cell suspension was ruptured by sonication at $100 \%$ amplitude for 5 min with 0.9 cycles and in other part ten time concentrated cell free supernatant of LABW4 was introduced in cell suspension and incubated at $37^{\circ} \mathrm{C}$ for $1 \mathrm{~h}$. The cell free supernatant was collected by centrifugation at $8000 \mathrm{rpm}$ for $5 \mathrm{~min}$ at $4^{\circ} \mathrm{C}$ and used as enzyme source. The untreated CFS was used as the negative control. The rate of reduced $\mathrm{NADH}$ oxidation was measured in $3 \mathrm{ml}$ cuvette at $37^{\circ} \mathrm{C}$ and $340 \mathrm{~nm}$ after 5 min incubation. For each test $2 \mathrm{ml}$ of Tris-chloride buffer (50 mM, pH 7.5), $150 \mu \mathrm{l}$ of NADH (20 mM) [SIGMA-ALDRICH, USA], $750 \mu$ of pyruvate (50 mM DC sodium form) [SIGMA-ALDRICH, USA] and $100 \mu \mathrm{l}$ of enzyme preparation were added to the cuvette. One unit of enzyme activity is defined as a rate of NADH oxidation of $1 \mu \mathrm{mol}$ per min per ml [13].

\subsection{Scanning Electron Microscopic Study}

To study the effect of bacteriocin produced by LABW4 on pathogenic bacterium, scanning electron microscopy was done for both treated and untreated L. monocytogenes. Listeria cells resuspended in $50 \mathrm{mM}$ Tris-chloride buffer (pH 7.5) was treated with $10 \%$ ten time concentrated cell free supernatant of LABW4 for 4 hours. Ten times concentrated MRS broth was used for control set. Cells were harvested by centrifugation at $6000 \mathrm{rpm}$ for 10 minutes and prepared for SEM studies. The cells were prefixed with $2 \%$ glutaraldehyde in $20 \mathrm{mM}$ Na-P buffer (pH 6.5) plus 5\% dimethyl sulphoxide (DMSO) [Merck, Germany] for 30 minute. After pre-fixation the cells were gently washed with $20 \mathrm{mM} \mathrm{Na}-\mathrm{P}$ buffer ( $\mathrm{pH}$ 6.5) and post fixed with osmium tetraoxide [SIGMAALDRICH, USA] dissolved in $50 \mathrm{mM}$ Na-P buffer ( $\mathrm{pH}$ 6.5). Cells were then dehydrated in series of alcohol grades starting from $30 \%$ to absolute alcohol, 10 minutes in every dilution. The dehydrated cells were coated with gold using an ion sputter (Coater IB-2, Gike Engineering, Japan) and observed under scanning electron microscope (HITACHI S-530, Japan) [14].

\subsection{Data Analysis}

The results presented are average of at least three observations. The means and standard deviations were calculated using Microsoft Excel 2007 program.

\section{Results}

\subsection{Isolation of Lactic Acid Bacteria}

The lactic acid bacterial strain LABW4 was isolated from the good quality fermented milk product. Initially numbers of bacterial colonies were isolated on MRS agar plates and finally the strain LABW4 was selected as a 
potent bacteriocin producer. LABW4 was able to produce prominent zone of inhibition (Figure 1) against bacteriocin sensitive strain Enterococcus faecalis MB1 (LAB8). Based on morphological, biochemical and 16S rRNA gene sequence homology studies the strain LABW4 was identified as Lactococcus lactis subsp. lactis. The cells were Gram positive non-motile, non-endospore forming cocci with lactose utilizing and catalase nonutilizing properties.

\subsection{Anti-Listerial Activity of Isolated Strain LABW4}

The antibacterial activity of LABW4 was checked against Listeria monocytogenes MTCC657 which is a Gram positive psychrophilic bacterium responsible for spoilage of meat and other food products. The isolated strain LABW4 produced distinct zone of inhibition against L.monocytogenes when checked by agar well diffusion method. Both the normal as well as heat killed cell free supernatant was effective to produce $12.5 \pm 0.5 \mathrm{~mm}$ zones of inhibition (Figure 2).

The anti listerial activity of LABW4 was also checked by counting the colony forming units of $L$. monocytogenes after treatment with cell free supernatant of LABW4. During this study it was found that the number of colony forming units decreased significantly with increased percentage of cell free supernatant of LABW4 (Table 1). Similar results were also obtained when heat killed supernatant was used (Table 1).

\subsection{Effect of Cell Free Supernatant of LABW4 on Growth Pattern of $L$ monocytogenes}

To check the mode of action of the cell free supernatant of LABW4 on L. monocytogenes, growth curve patterns of Listeria were studied in the presence and absence of cell free supernatant of LABW4. From the growth curve pattern it was found that the number of CFUs decreased rapidly after the addition of LABW4 supernatant and in next 10 hours, all the cells died (Figure 3).

\subsection{Control of Spoilage of Meat Caused by L. monocytogenes}

The anti-listerial activity of LABW4 was also checked by in vivo challenge study where we have tried to control

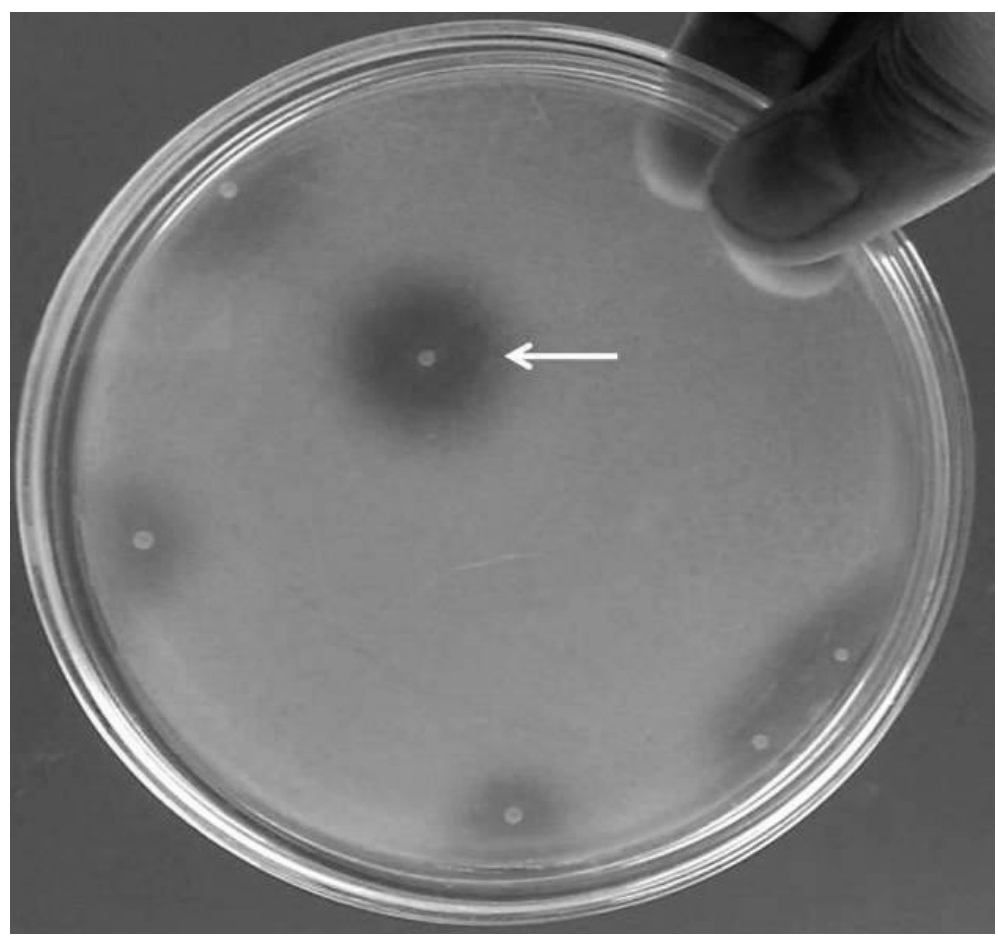

Figure 1. Zone of inhibition produced by Lactic acid bacterial strain LABW4 against bacteriocin sensitive Enterococcus faecalis MB1 (LAB8) on dual culture overlay plate. 


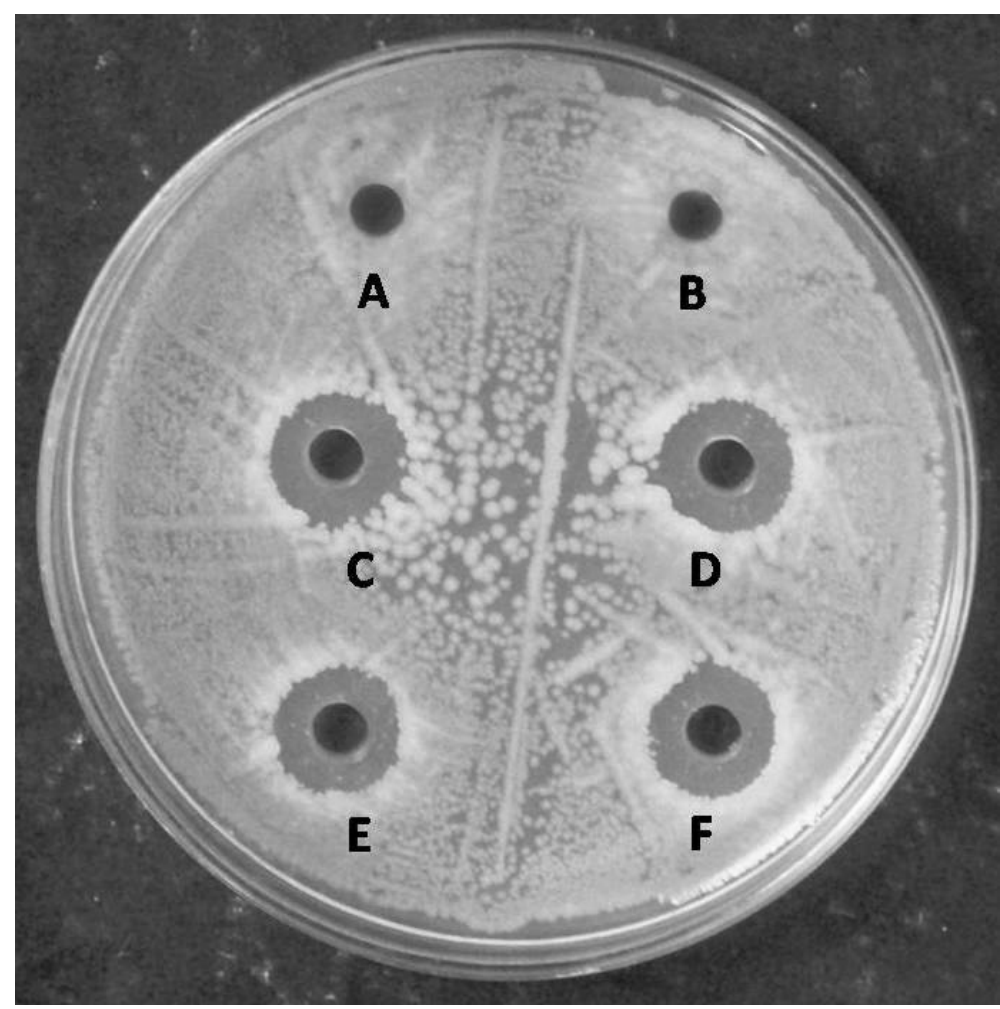

Figure 2. Zones of inhibition produced by cell free supernatant (CFS) of LABW4 against Listeria monocytogenes MTCC657: (A) \& (B) control; (C) \& (D) normal cell free supernatant; (E) \& (F) Heat killed cell free supernatant.

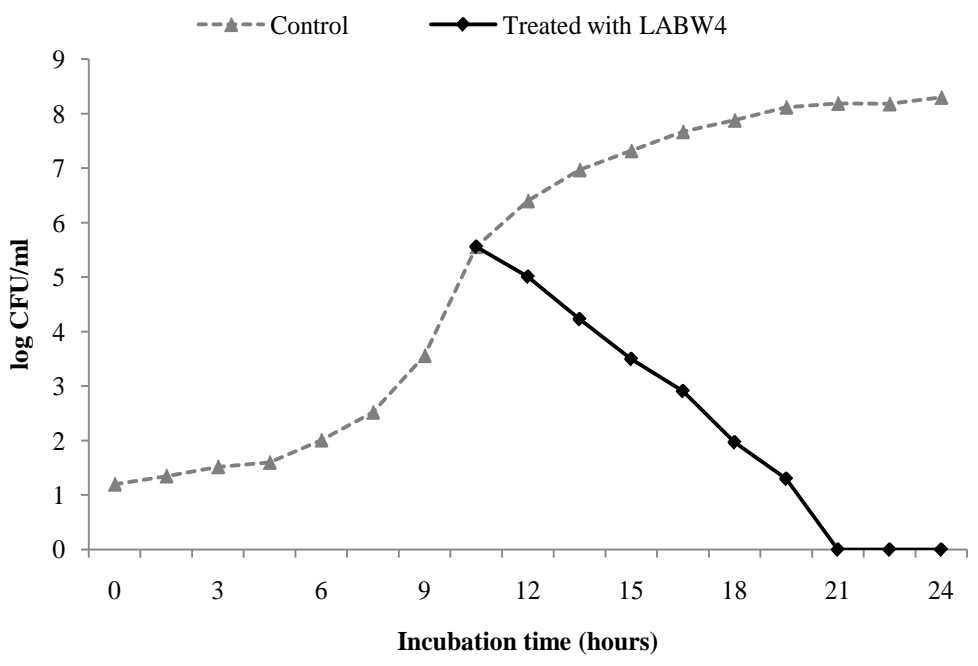

Figure 3. Effect of cell free supernatant of LABW4 on the growth of Listeria moocytogenes MTCC657. The results were the mean of triplicate trials.

the spoilage of meat samples using LABW4. It was found that the cell free supernatant of LABW4 was also able to inhibit the growth of $L$. monocytogenes in meat samples and therefore able to prevent the spoilage of meat up to 25 days or more at $4^{\circ} \mathrm{C}$. When the characteristics of meat samples were checked it was also found that spoilage of meat started within 24 hours in case of control set. When the colony forming units of Listeria were counted from meat samples, only negligible numbers of $1.08 \times 10^{1} \mathrm{CFUs}$ in 10 days were found in case of LABW4 treated samples in comparison to its untreated control (Figure 4). 
Table 1. Number of colony forming units of $L$. monocytogenes after treatment with cell free supernatant of LABW4.

\begin{tabular}{|c|c|c|c|}
\hline \multirow[t]{2}{*}{ Control (CFU/ml) } & \multicolumn{3}{|c|}{ Treated with cell free supernatant of LABW4 } \\
\hline & 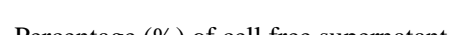 & & \\
\hline & & Unboiled & Boiled \\
\hline & 1 & $7.5 \times 10^{8}$ & $8.9 \times 10^{8}$ \\
\hline & 2 & $6.9 \times 10^{8}$ & $8.6 \times 10^{8}$ \\
\hline & 3 & $5.6 \times 10^{7}$ & $6.9 \times 10^{7}$ \\
\hline \multirow[t]{7}{*}{$9.1 \times 10^{8}$} & 4 & $2.1 \times 10^{7}$ & $2.7 \times 10^{7}$ \\
\hline & 5 & $7.6 \times 10^{6}$ & $8.1 \times 10^{6}$ \\
\hline & 6 & $3.2 \times 10^{6}$ & $3.8 \times 10^{6}$ \\
\hline & 7 & $6.3 \times 10^{4}$ & $7.4 \times 10^{4}$ \\
\hline & 8 & $9.2 \times 10^{2}$ & $9.6 \times 10^{2}$ \\
\hline & 9 & 0 & 0 \\
\hline & 10 & 0 & 0 \\
\hline
\end{tabular}

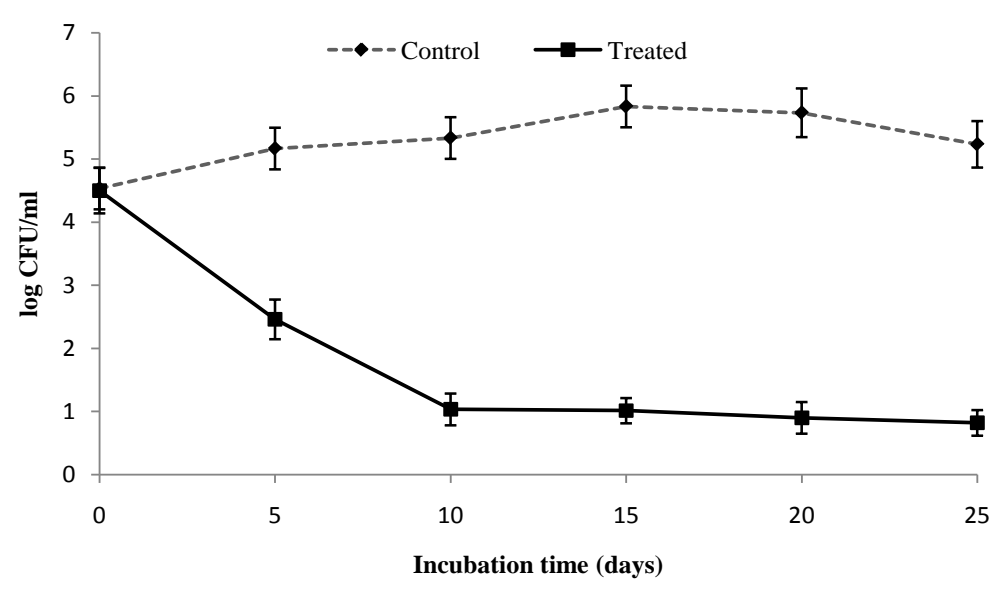

Figure 4. Numbers of Listeria monocytogenes in meat samples by cell free supernatant of LABW4 after storage at $4^{\circ} \mathrm{C}$. The results were the mean of triplicate trials.

\subsection{Lactate dehydrogenase Assay}

It was found that treatment of Listeria cells with ten time concentrated cell free supernatant of LABW4 significantly enhanced the LDH activity in comparison to its untreated control (Figure 5). The increase of LDH activity after treatment indicated leakiness or lysis of bacterial cell membrane to release of LDH into extracellular environment.

\subsection{Effect of Cell Free Supernatant of LABW4 on Morphology of L. monocytogenes}

Scanning electron microscopic study was performed to observe the morphological changes of $L$. moncytogenes after treatment with ten time concentrated cell free supernatant of LABW4. During this study it was observed that cell free supernatant significantly affected the cellular morphologies of L. monocytogenes. Degradations of wall structures were noticed in case of treated cells which supported the lytic mode of action of bacteriocin (Figure 6(b) \& Figure 6(c)). In some cases shrinkages of treated cells were also observed which may be due to 


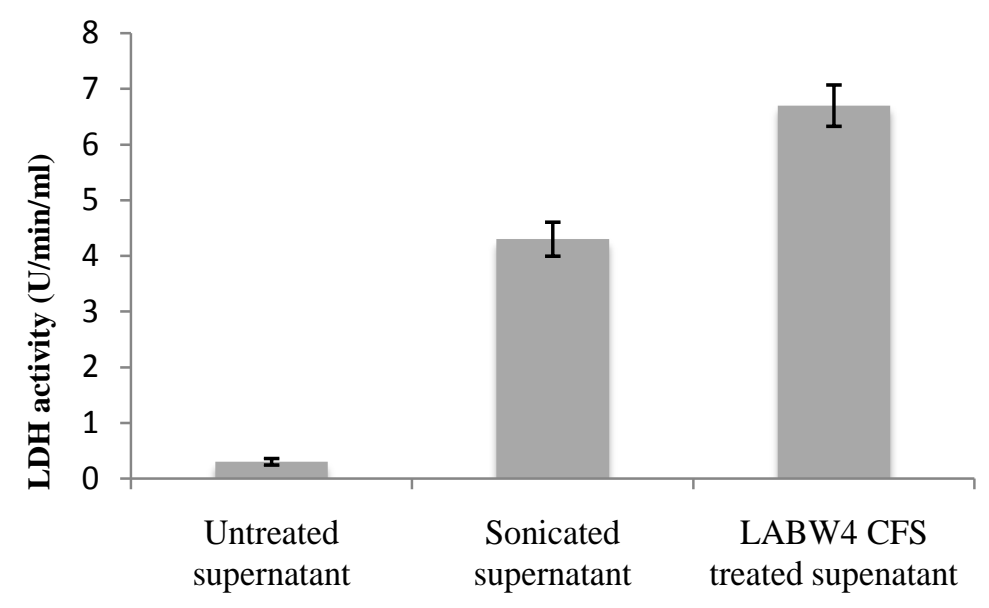

Treatment conditions

Figure 5. Lactate dehydrogenase assay of Listeria monocytogenes MTCC657.

Values were the averages of three independent trials.

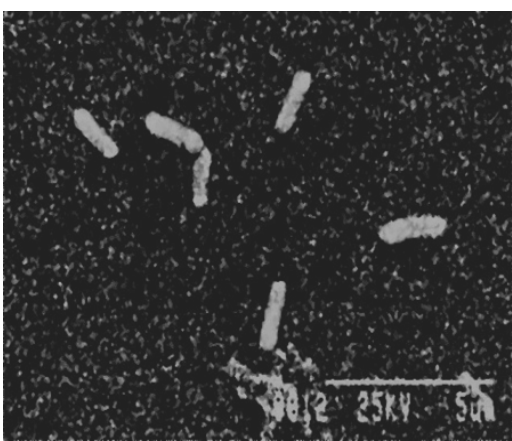

(a)

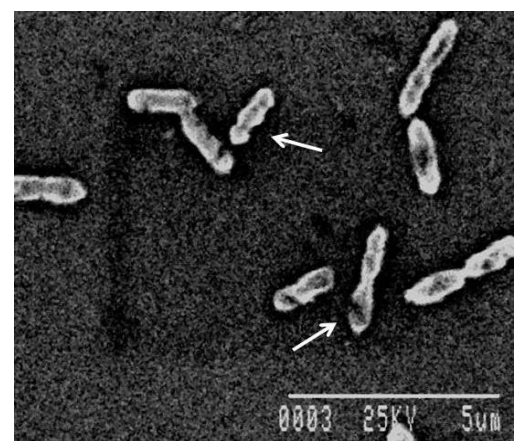

(b)

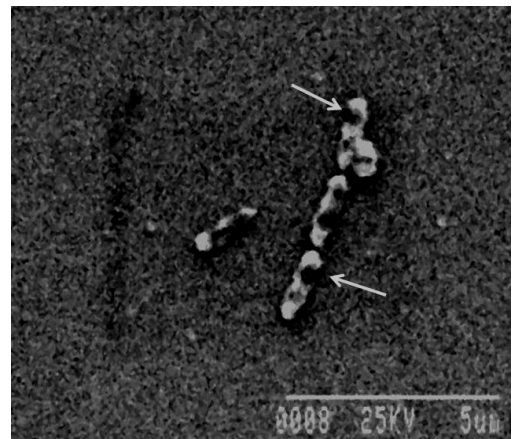

(c)

Figure 6. Scanning electron micrographs of Listeria monocytogenes: (a) untreated; (b) \& (c) Treated with cell free supernatant of LABW4 for 4 hours.

loss of internal cellular fluids after treatments (Figure 6(b) \& Figure 6(c)). No such degradations or shrinkages were noticed in untreated cells (Figure 6(a)).

\section{Discussion}

The isolated food grade lactic acid bacterial strain Lactococcus lactis subsp. lactis was effective to produce significant zone of inhibition against L. monocytogenes. Inhibition zone produced by cell supernatant indicated the secretion of antibacterial principle to the extracellular environment. The antibacterial potential of heat killed supernatant also supported the thermostable nature of the antibacterial compound(s). Loss of antibacterial activity after treatment with proteinase $\mathrm{K}$ demonstrated the proteinaceous nature of the antibacterial metabolite(s). It has already been reported by several workers that the bacteriocin produced by lactic acid bacteria are highly thermostable proteinaceous compounds which showed anti bacterial activity even after autoclaving (121 $\left.{ }^{\circ} \mathrm{C}\right)$ [15]. Significant decreases in the numbers of colony forming units of $L$. monocytogenes were also noticed after treatment with cell free supernatant of LABW4. Pinto et al. [16] have reported the antilisterial activities of bacteriocin produced by Enterococcus faecium and Pediococcus pentosaceus. Cosentino et al. [17] have checked the antimicrobial properties of 117 Lactococcus lactis subsp. lactis isolated from artisanal Sardinian dairy products of which six strains were found to produce bacteriocin-like substances having anti-listerial activity. To check the mode of action of the antibacterial metabolites cell free supernatant of LABW4 was added to mid log phase of $L$. monocytogenes. A rapid downward trend of growth curve in treated set indicated the strong cidal nature of the antibacterial molecule(s) on L. monocytogenes. 
During in vivo challenge studies using meat samples it was found that cell free supernatant of LABW4 was highly effective to prevent the spoilage of meat samples upto 25 days or more at $4^{\circ} \mathrm{C}$ even after the treatment with high concentration of spoilage pathogen $L$. monocytogenes. As LABW4 is a bacteriocin producing strain therefore it is assumed that it produces sufficient bacteriocin to prevent the growth of $L$. monocytogenes. Presence of lactic acid in the medium also decreased the medium $\mathrm{pH}$ and creates an acidic environment which may also inhibit the growth of $L$. monocytogenes. L. monocytogenes has been shown to be able to grow under a variety of conditions. It is able to survive and grow on meat and meat products at refrigeration temperatures. The organism is able to survive in acid conditions with $\mathrm{pH}$ as low as 4.8 in foods and as low as 4.4 in laboratory media. Nielsen et al. [18] reported an inhibitory and bactericidal effect of a bacteriocin produced by Pediococcus acidilactici on L. monocytogenes associated with spoilage of fresh meat.

Lactate dehydrogenase (LDH) is a cytoplasmic enzyme and its activity is routinely used to measure the cellular integrity [13]. The significant increase in LDH activity of $L$. monocytogenes after treatment indicated the lytic mode of action of the bacteriocin produced by LABW4. This type of observation was also reported by previous workers [13]. The lysis of treated cells was also evidentially proved when prominent degradations of wall structures were observed by scanning electron microscopic studies. Such type of cell lysis was also reported in case of Pediococus acidilactici B1153 treated with bacteriocin from Pediococcus pentosaceus CFR SIII [19]. On the other hand Mandal et al. [13] reported pore formation in case L. monocytogenes by bacteriocin of Pediococcus acidilactici LAB 5.

\section{Conclusion}

Lactococcus lactis subsp. lactis LABW4 was able to inhibit the growth and activity of Listeria monocytogenes and was effective for long-term preservation of meat samples under refrigeration. It showed strong cidal effect and lytic mode of action on Listeria monocytogenes which cause severe meat-spoilage. Traditional methods of preservation such as refrigeration, pasteurization, and low $\mathrm{pH}$ are not completely effective in controlling or eliminating L. monocytogenes from food. The use of lactic acid bacteria or its metabolite(s) in combination with traditional methods of preservation could be effective in controlling L. monocytogenes to prevent spoilage of meat products. The lactic acid bacteria also have GRAS status and several probiotic activities, therefore using of such organism to preserve the food products may also confer various health benefits.

\section{References}

[1] Daeschel, M.A. (1989) Antimicrobial Substances from Acid Lactic Bacteria for Use as Food Preservative. Food Technology, 43, 164-167.

[2] Khalid, K. (2011) An Overview of Lactic Acid Bacteria. International Journal of Biosciences, 1, 1-13.

[3] Farber, J.M. and Peterkin, P.I. (1991) Listeria monocytogenes, a Food-Borne Pathogen. Microbiological Review, 55, 476-511.

[4] Cole, M.B., Jones, M.V. and Holyoak, C. (1990) The Effect of pH, Salt Concentration and Temperature on the Survival and Growth of Listeria monocytogenes. Journal of Applied Bacteriology, 69, 63-72. http://dx.doi.org/10.1111/j.1365-2672.1990.tb02912.x

[5] Gandhi, M. and Chikindas, M.L. (2007) Listeria: A Foodborne Pathogen That Knows How to Survive. International Journal of Food Microbiology, 113, 1-15. http://dx.doi.org/10.1016/j.ijfoodmicro.2006.07.008

[6] Pucci, M.J., Vedamuthu, E.R., Kunka, B.S. and Vandenbergh, P.A. (1988) Inhibition of Listeria monocytogenes by Using Bacteriocin PA-1 Produced by Pediococcus acidilactici PAC 1.0. Applied and Environmental Microbiology, 54, 2349-2353.

[7] Buyong, N., Kok, J. and Luchansky, J.B. (1998) Use of a Genetically Enhanced, Pediocin-Producing Starter Culture, Lactococcus lactis subsp. lactis MM217, to Control Listeria monocytogenes in Cheddar Cheese. Applied and Environmental Microbiology, 64, 4842-4845.

[8] De Man, J.C., Rogosa, M. and Sharpe, M.E. (1960) A Medium for the Cultivation of Lactobacilli. Journal of Applied Bacteriology, 23, 130-135. http://dx.doi.org/10.1111/j.1365-2672.1960.tb00188.x

[9] Magnusson, J., Ström, K., Roos, S., Sjögren, J. and Schnürer, J. (2003) Broad and Complex Antifungal Activity among Environmental Isolates of Lactic Acid Bacteria. Applied and Environmental Microbiology, 219, 129-135.

[10] Fernández-Garayzábal, J.F., Delgado, C., Blanco, M., Vázquez-Boland, J.A., Briones, V., Suárez, G. and Domínguez, L. (1992) Role of Potassium Tellurite and Brain Heart Infusion in Expression of the Hemolytic Phenotype of Listeria spp. on Agar Plates. Applied and Environmental Microbiology, 58, 434-438. 
[11] Brahmachari, G., Mandal, N.C., Roy, R., Ghosh, R., Barman, S., Sarkar S., Jash, S.K. and Mondal, S. (2013) A New Pentacyclictriterpene with Potent Antibacterial Activity from Limnophila indica Linn. (Druce). Fitoterapia, 90, $104-$ 111. http://dx.doi.org/10.1016/j.fitote.2013.07.012

[12] Stockland, A.E. and San Clemente, C.L. (1968) Lactate dehydrogenase Activity in Certain Strains of Staphylococcus aureus. Journal of Bacteriology, 95, 74-80.

[13] Mandal, V., Sen, S.K. and Mandal, N.C. (2010) Assessment of Antibacterial Activities of Pediocin Produced by Pediococcus acidilactici Lab 5. Journal of Food Safety, 30, 635-651.

[14] Mandal, V., Sen, S.K. and Mandal, N.C. (2008) Optimized Culture Conditions for Bacteriocin Production by Pediococcus acidilactici LAB 5 and Its Characterization. Indian Journal of Biochemistry and Biophysics, 45, 106-111.

[15] Mandal, V., Sen, S.K. and Mandal, N.C. (2013) Production and Partial Characterization of an Inducer Dependent Novel Antifungal Compound(s) by Pediococcus acidilactici LAB5. Journal of Science of Food and Agriculture, 93, 2445-2453. http://dx.doi.org/10.1002/jsfa.6055

[16] Pinto, A.L., Fernandes, M., Pinto, C., Albano, H., Castilho, F., Teixeira, P. and Gibbs, P.A. (2009) Characterization of Anti-Listeria Bacteriocins Isolated from Shellfish: Potential Antimicrobials to Control Non-Fermented Seafood. International Journal of Food Microbiology, 129, 50-58. http://dx.doi.org/10.1016/j.ijfoodmicro.2008.11.005

[17] Cosentino, S., Fadda, M.E., Deplano, M., Melis, R., Pomata, R. and Pisano, M.B. (2012) Antilisterial Activity of Nisin-Like Bacteriocin-Producing Lactococcus lactis subsp. lactis Isolated from Traditional Sardinian Dairy Products. Journal of Biomedicine and Biotechnology, 2012, 1-8. http://dx.doi.org/10.1155/2012/376428

[18] Nielsen, J.W., Dickson, J.S. and Crouse, J.D. (1990) Use of a Bacteriocin Produced by Pediococcus acidilactici to Inhibit Listeria monocytogenes Associated with Fresh Meat. Applied and Environmental Microbiology, 56, 2142-2145.

[19] Halami, P.M., Badrinath, V., Devi, S.M. and Vijayendra, S.V.N. (2011) Partial Characterization of Heat-Stable, Antilisterial and Cell Lytic Bacteriocin of Pediococcus pentosaceus CFR SIII Isolated from a Vegetable Source. Annals of Microbiology, 61, 323-330. http://dx.doi.org/10.1007/s13213-010-0145-X 
Scientific Research Publishing (SCIRP) is one of the largest Open Access journal publishers. It is currently publishing more than 200 open access, online, peer-reviewed journals covering a wide range of academic disciplines. SCIRP serves the worldwide academic communities and contributes to the progress and application of science with its publication.

Other selected journals from SCIRP are listed as below. Submit your manuscript to us via either submit@scirp.org or Online Submission Portal.
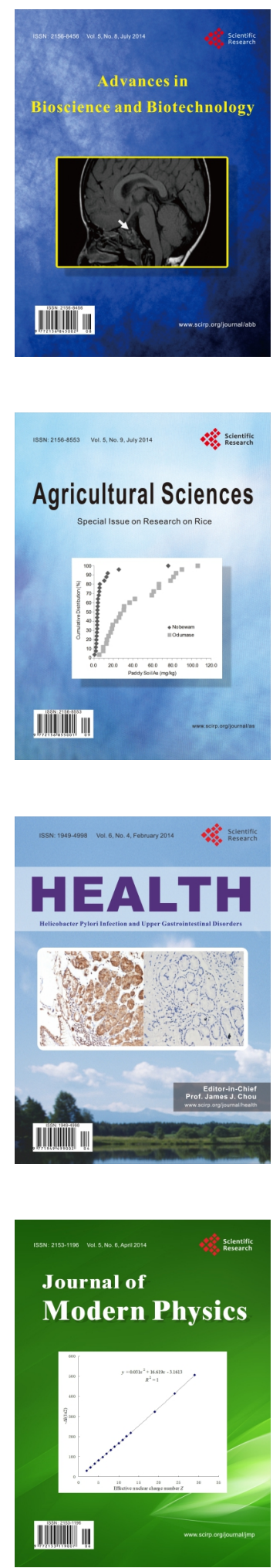
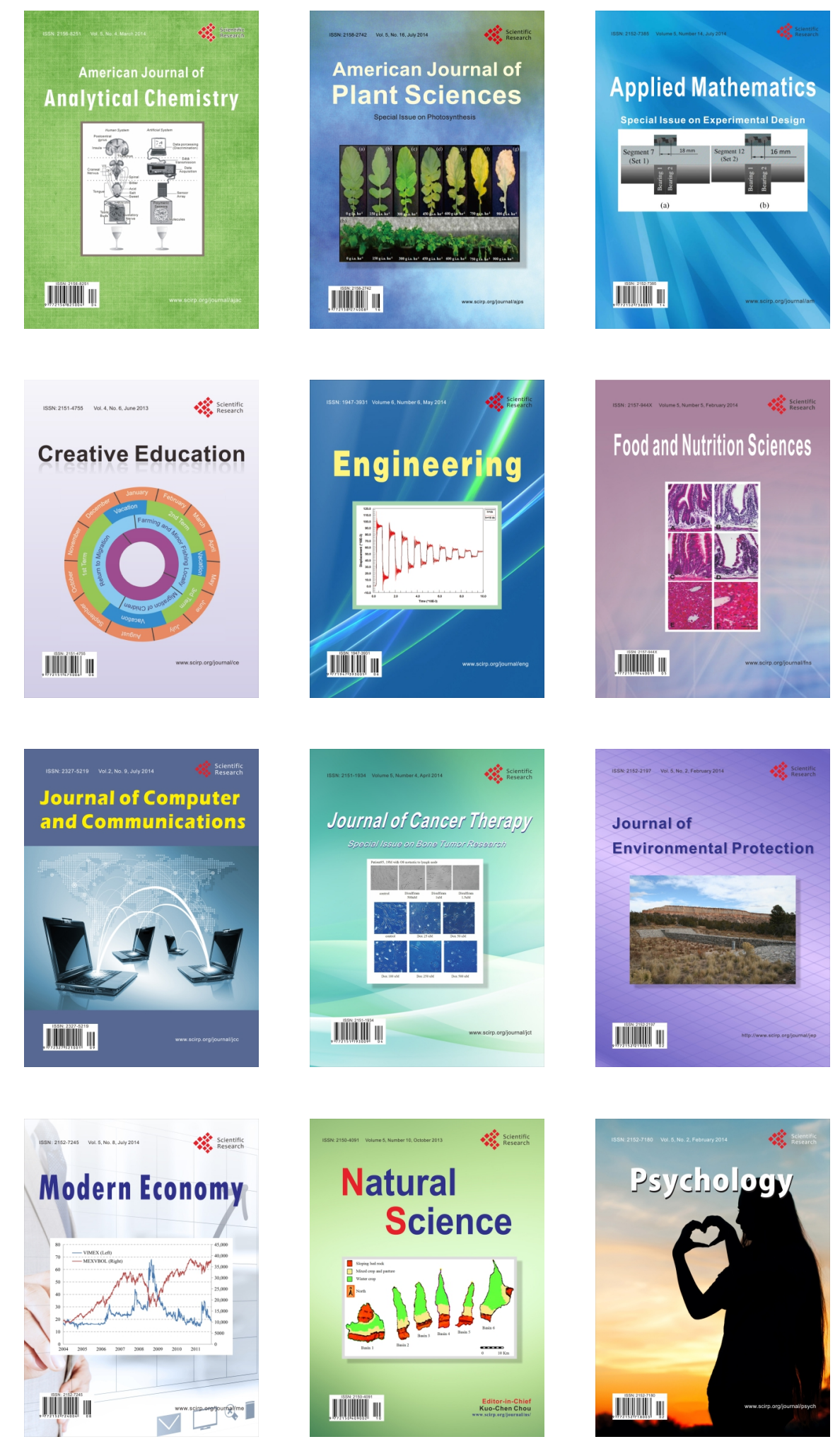